\title{
PARTICIPATION OF THE MONTENEGRIN METROPOLITAN VISARION IN THE FIRST PHASE OF NEGOTIATIONS BETWEEN MONTENEGRO AND THE HOLY SEE ABOUT CONCORDAT
}

\author{
Dragan Radoman \\ Seminary of Saint Peter of Cetinje, Cetinje \\ Prof. Mirko Kulić, PhD \\ University Business Academy in Novi Sad, \\ Faculty of Law for Commerce and Judiciary, Novi Sad \\ Jelena Gluščević, $\mathrm{PhD}$ \\ University Business Academy in Novi Sad, \\ Faculty of Contemporary Arts, Belgrade
}

mmediately after acquiring state independence at the Berlin Congress,

in 1878, Prince Nikola initiated negotiations with the Vatican for concluding a Concordat, which would regulate the position of the inhabitants of the Catholic faith in Montenegro. The first mediator was Bishop Strossmayer, and from the summer of 1881 the negotiations continued through the personal envoy, the bishop Visarion Ljubiša, the last metropolitan of Montenegro. The paper gives a synthetic presentation of the participation of this Orthodox ecclesiastical dignitary in defining the first draft of Concordat, as well as his role in negotiations with the highest representatives of Curia, during which his adherence to principles and high awareness of the importance of the task entrusted to him by the highest state authority were expressed.

Key Words: Concordat, Montenegro, Vatican, Visarion Ljubiša, Prince Nikola, Strossmayer, Austria, Pope, Cardinal, Nuncio

Erom the beginning of the pontificate of the Pope Leo XIII (February 1878), the

Roman Curia took a special position towards Eastern Europe, which was expressed in an increased interest in local Christian nations. Efforts were made in order to stimulate dialogue with the Orthodox world and make the unification of the Catholic and Orthodox Church possible in the future. The Concordat that the Holy See concluded with the Principality of Montenegro, a small Balkan country, on August 18, 1886, could seem like a modest and marginal event. The view of long and arduous road, which led to the arrangement of the relations between Rome and Cetinje, however, gives a completely different picture. A search for mutually acceptable agreement lasted for eight years and it included, on the one hand, people from the top of the Catholic Church, Pope Leo XIII and his state secretaries, first of all Cardinal Nino, then his successor Jakobini, and, on 
the other hand, two most impressive representatives of the South Slavic world at that time: Prince Nikola Petrović Njegoš and Bishop Josip Juraj Strossmayer. After all, it could not have been otherwise, bearing in mind that the Concordat of 1886, in fact, was the first Concordat aimed at arranging relations between the Holy See and an Orthodox state, with all the problems of political, legal and religious nature, which followed its creation, and with all the hopes and expectations it aroused in both contracting parties. ${ }^{1}$

The sequence of the events that led to the Concordat of 1886 was caused by major crisis that hit the Balkan Peninsula in the second half of the seventies. At that time, the small Principality of Montenegro, with its ruler, Prince Nikola Petrović Njegoš, attracted the attention of European offices and international public opinion, at the beginning by providing support to the Christian people, who rebelled against the Ottoman authorities in Bosnia and Herzegovina, and then by the main role in the series of victorious war endeavors against the Sultan's army. These successes on the battlefield were crowned at the political and diplomatic level in 1878, at the Berlin Congress, where Montenegro gained its independence, and when several important territories from the Ottoman Empire were ceded to it. Despite the fact that these ceded territories did not fully satisfy the expectations of Prince Nikola and were somehow darkened by transferring the governance over Bosnia and Herzegovina to the Habsburg Monarchy, nevertheless, they enabled this Balkan state to double its territory, extending from all sides the historical core of the old Montenegro and Hills, and providing it access to the sea through Antivari, that is, Bar.

Despite its limited resources, during the rule of the Petrović Njegoš dynasty, Montenegro was accredited as the force worthy of respect on the Balkan scene, and it could expect a central role in the process of uniting Serbs, and even all the South Slavs. ${ }^{2}$

With the territorial expansion and increase in the population of Montenegro, the ethnic and religious composition of the population also changed. It ceased to be, almost entirely, a nationally and religiously homogeneous state, since its borders included Turks and Albanians, Muslims and Catholics. This change caused problems, since the Montenegrin identity was firmly rooted in the cruel struggle, which the Orthodox Slavic brotherhoods and tribes waged against the Muslims for centuries, but it was to a certain degree stirred up by the lack of confidence against 'Latin', which was, after all, to a great extent double-sided. In such conditions, the arrangement of the position of new national and religious minorities was set up as one of the priorities of Prince Nikola. It was not just about fulfilling the clauses from the Berlin Congress, which clearly stipulated that the new independent states in the Balkans including Montenegro had to implement the policy of religious tolerance in the territories granted to them by the Ottoman Empire. Even if these international obligations were ignored, it was clear that finding a balanced solution, which could guarantee the strengthening of the central government over non-Slavic people, and which, at the same time, could respond to some of its legitimate needs and avoid the outbreak of tensions, would represent one of the parameters for evaluating the ability of the Montenegrin authorities to change traditional structures of brotherhoods and tribes and at least partially modernize the state. ${ }^{3}$

\footnotetext{
${ }^{1}$ Francesco Kakamo, the Concordat with Montenegro and the policy of the Holy See towards the East. http://www.montenegrina.net/pages/pages1/religija/konkordat_sa_cg.htm (August 9, 2018)

${ }^{2}$ Rados Ljusic. History of Serbian Statehood - Serbia and Montenegro, Vol. 2, Novi Sad 2011, 337-354.

${ }^{3}$ http://www.montenegrina.net/pages/pages1/religija/konkordat_sa_cg.htm (August 9, 2018)
} 
Participation of the Montenegrin Metropolitan Visarion in the First Phase of Negotiations between Montenegro ...

Concerning specifically Catholic population in Montenegro, it was not more than a few thousand people, from 4,000 to 6,000, according to some estimates, and it mostly consisted of Albanians, and to a lesser extent Slavs. In spite of its numerical insignificance and ethnic fragmentation, this Catholic component caused considerable problems. While it was easy to anticipate that the international community would not take much care of fulfilling the obligations to Muslims determined by the Berlin Congress, the situation was different in relation to Catholics, who counted on diplomatic protection and financial help from powerful Catholic countries, such as Austria-Hungary, France, and Italy, as it was the case during the previous centuries under the Turkish rule. In addition, it was obvious that the attitude of Prince Nikola and his administration towards them would significantly influence the future of Montenegro. ${ }^{4}$

The conclusion of Concordat between the Vatican and Montenegro was a long process, which went through several phases. Since it was the first Concordat that the Holy See concluded with an Orthodox country, it was necessary to harmonize many factors and interests. Many eyes of those with good intentions and even more of those with not good intentions, carefully watched the progress of creating this legal agreement. Bearing in mind that during this period Austria-Hungary sponsored the Catholic Church in the territory of a larger part of the Balkan Peninsula, it was clear that its political plans did not correspond to concluding the Concordat between the Holy See and Montenegro. On the other hand, having in mind the modest intellectual and administrative capacity of the persons, who surrounded Prince in Cetinje, it is clear that for such important question he had to find a person, who had his absolute confidence on the one hand, and on the other hand, the one who, at the same time, had the ability to come face-to-face with an extremely delicate task and interlocutors from the Vatican diplomacy and Curia, who were inviolable in diplomatic negotiations. Having no great choice of associates, and having confidence in the loyalty to the interests of the Orthodox faith and state-legal continuity based on medieval NemanjićCrnojević heritage, several facts made Prince Nikola include Visarion Ljubiša, the bishop of Zahumlje and Raška, in the process of preparation and conclusion of the Concordat and entrusted him with drafting the text of the Concordat. ${ }^{5}$ He was born in the Littoral region and therefore he learned Italian as part of elementary and theological education. ${ }^{6}$ Serving in monastic rank in monasteries in the Bay of Kotor and Paštrovići, he had enough insight

\footnotetext{
${ }^{4}$ Radoslav Raspopovic, Diplomacy of Montenegro 1711-1918. Historical Institute, Podgorica 1996, 487-488; http://www.montenegrina.net/pages/pages1/religija/konkordat_sa_cg.htm (August 9, 2018)

${ }^{5}$ Metropolitan Visarion was born on January 14, 1823 in Sveti Stefan, Paštrovići. After completing monastic education, he was a teacher in the monasteries Praskvica, Reževići and Savina, and then a parish and a teacher in Perast. After coming to Montenegro, he became the head of the Morača monastery, with the title of Archimandrite. He was set to Bishop of Zahumlje-Raška, with the center in Ostrog Monastery, on September 8 , 1878. He became the Metropolitan of Montenegro and Hills on December 6, 1882.

His work on the reform of church-educational life was interrupted by his death, on April 14, 1884, in Cetinje, where he was buried. Sava, Bishop of Sumadija, Serbian Hierarchs from the 9th to the 20th century, Belgrade 1997, 88-89.

${ }^{6}$ In addition to the primary school in Budva, Visarion finished one - year preparatory school in Italian, in Šibenik, 1838/39, and from the preserved diploma, it can be seen that, in addition to the Italian language and literature, he also studied Latin and literature with writing. The original diploma is kept in the personal legacy of the Metropolitan Visarion Ljubiša, the Archives of the Praskvica Monastery.

The Italian language, as the official language at that time, was a compulsory subject in the School of Clergy Seminary, which Visarion attended in Šibenik and Zadar, 1839-1844. The original diploma is in the State Archives of Montenegro - Department in Budva, Legacy of Ljubiša family.
} 
into the spirit and structure of the Roman Catholic Church, at least at the local level. After all, during these years, at the beginning of the 1880s, the state administration in Montenegro had just begun to form, and it consisted mostly of people born and educated abroad, but they came with good will to serve the interests of the 'Serbian Sparta', as they affectionately called Montenegro. The other, and a very important reason, which induced Prince Nikola to involve Bishop Visarion in negotiating process for the Concordat and entrust him with the leading role on the Montenegrin side in this work, was to secure, from the Orthodox side, domestic and even more Russian, acceptability of the drafted contract. The powerful Russia was especially sensitive to any contact with the Vatican, and especially to such important question as it was defining the legal position of the Catholic Church in a dominantly orthodox country, which has survived for three centuries, mostly owing to the political protection and material help of the Russian Empire. ${ }^{7}$

Undoubtedly, the process of drafting the Concordat required a certain period of preparation, during which Bishop Visarion had to be acquainted with the contents of, at least, some of the most important Concordats that the Holy See had concluded with some of the European countries. The result of his work was the draft Concordat, which consisted of 34 articles. Since Prince Nikola became acquainted with its content and approved it, the negotiations with the Roman Curia could begin. That is why Bishop Visarion, under the order of Prince Nikola, went to Rome with the draft Concordat and wide permissions to negotiate with the representatives of the Roman Curia about the harmonization of the text of the Concordat, on June $14,1881 .{ }^{8}$ The main topics of the negotiations were the question of the legal position of the Catholic Church, its attitude towards the Prince Nikola's government and the question of mixed marriages (Catholic-Orthodox), as well as the question of the competencies of the Prince Nikola's authority regarding the appointment of the Archbishop of Bar. In the organization of the Bishop Visarion's journey to Rome, as well as the process of drafting the Concordat, the Italian Minister in Montenegro, Durando, was also involved. In his report submitted to the Ministry of Foreign Affairs of Italy, on July 2, 1881, Durando stated that Bishop Visarion started his journey to Rome on June 28 (June 14 according to the old calendar, which was valid in Montenegro) with the Concordat project, which he characterized in this way: 'It cannot be more liberal. ${ }^{9}$ During the summer of 1881 , Visarion spent a month in Rome, negotiating with the State Secretary of the Holy See, Cardinal Ludovic Jakobini, but without success. ${ }^{10}$ During his stay in Rome, he was not allowed to meet with Pope Leo XIII because of protocol reasons that were incompatible with his position as

\footnotetext{
${ }^{7}$ Pavle Kondic, Metropolitanate of Montenegro and the Littoral in the second half of the 19th and early 20th century (1851-1920), Belgrade 2014, 158-163. Manuscript, a copy in the Metropolitanate Library, in Cetinje.

${ }^{8}$ Visarion was in Italy in the summer of 1872 , as it can be seen from the passport that is kept in the personal legacy of the Metropolitan Visarion, the Archives of the Praskvica Monastery. Passport for the trip to Rome was issued to him on June 16, 1881 under no. 482. Itemized protocols of issued passports in Principality of Montenegro (1879-1883), Vol. II, the State Archives of Montenegro, Cetinje 2013, 68.

${ }^{9}$ Gligor Stanojevic, 'Contributions to Diplomatic History of Montenegro from the Berlin Congress until the end of the XIX century', Historical Journal, Vol. 11 (1960), 166

${ }^{10}$ Ludovic Jakobini (1832-1887), Italian, is one of the influential prelates of the Roman Curia in the middle and the second half of the XIX century. He was a Titular Archbishop in Thessaloniki since 1874 and a Cardinal since 1880. He performed a number of responsible duties in the diplomacy of the Holy See, at the place of Nuncio in Vienna in 1874-1880 and in Roman Curia in the post of Secretary of State 1880-1887. http://en.wikipedia.org/wiki/Luigi_Jacobini; http://www.catholic-hierarchy.org/bishop/bjaco.html (June 20, 2018)
} 
Participation of the Montenegrin Metropolitan Visarion in the First Phase of Negotiations between Montenegro ...

an Orthodox Archbishop. ${ }^{11}$ At that time, and all the time until the reform of the Roman Catholic Church at the Second Vatican Council (1963-1965), the ceremonial Pope honoring by kneeling, with unveiled head and kissing the ring on his right hand, which was a compulsory form of showing respect and submissiveness, for all bishops, priests and people, was in effect.

There are several modern testimonies to the participation of the Bishop Visarion at the initial stage of the negotiations with the Roman Curia about the position of the Roman Catholic Church in Montenegro in the documents of Bishop Josip Juraj Strossmayer, who led these negotiations with Prince Nikola. Through his correspondence with Prince Nikola on this occasion, for a long time from 1879 to 1886, there was a trace of Visarion's mission, even though it was kept in strict confidentiality. ${ }^{12}$ In the letter, which dates back to the second half of September 1883 that was the answer to Strossmayer's letter of September 10, Prince Nikola stated the attitude of the Concordat in unusually poor and precise way: '... I am very sorry that, answering your kind letter of September 10 , of this year, I must say, as it seems to me, that the Holy See would like to make the appointment of the Catholic bishop in Bar dependent on the conditions proposed to the reverend Mr. Ljubiša during his stay in Rome. If that were the case, now I would be obliged to state once again that, with the proposal of the Concordat which was then submitted to the Holy See by the bishop of Montenegro, we come to the final limits in the concessions that Montenegro can make to the Catholic Church, without buying the contract with the Holy See at the price of its dignity. These concessions truly set up a Catholic church, which has a maximum of 4,000 souls, perfectly at the same level of equality with the Orthodox Church, to which the vast majority of my people belong. ${ }^{.13}$

The intermediary role of Bishop Strossmayer in contact establishing and defining the text of the Concordat can be seen from the contents of the correspondence he conducted with the papal nuncio in Vienna, Archbishop Serafino Vannutelli. ${ }^{14}$ In the report that dates back to May 25, 1883, which he sent to the State Secretary Cardinal Jakobini, besides describing the conversation with Prince Nikola regarding the establishment of the Concordat, among other things, Vannutelli stated the following: 'I am very sad that the mission with the Holy See, for which I put in charge the Metropolitan of our church, for two years or less, did not succeed. ${ }^{15}$ And in the letter that dates back to July 10 ,

\footnotetext{
${ }^{11}$ Nina Hitrova, 'The Concordat of Montenegro with the Vatican (1886) and Russia', Historical Records, yr. LXXIII, no. 1-2, (2000), 180.

${ }^{12}$ Our search in the archives of the Metropolitanate of Montenegro and the Littoral, on this occasion, did not give the results because there was not a single note or document related to the topic. We have borne in mind the published sources and discussions so far. The documents from the State and Palace Archives in Cetinje were used by Risto Dragićević in the discussion 'The contract between the Holy See and the Principality of Montenegro 1886', Records, vol. 13, Vol. 24, (1935), 81-86.

${ }^{13}$ Records, yr. 8, Vol. 13, (1935), 102-103.

${ }^{14}$ Serafino Vannutelli (1834-1915), the Italian prelate, built very successful career in the diplomacy of the Roman Curia. After the diplomatic service in South America, he was the papal Nuncio in Brussels (1874-1880) and Vienna (1880-1893), Archbishop in Bologna (1893-1899) with the title of Cardinal and then the Great Penitentiary of the Roman Curia, until the death in 1915. http://en.wikipedia.org/wiki/Serafino_Vannutelli; http://www.catholic-hierarchy.org/bishop/bvan.html (June 20, 2018)

${ }^{15}$ Correspondence Josip Juraj Strossmayer - Serafino Vannutelli 1881-1887. Edited J. Balobanic and J. Kolanovic, Zagreb 1999, 259.
} 
1883, which Strossmayer sent to Cardinal Jakobini, through the nuncio Vannutelli, the participation of the Metropolitan Visarion during the negotiations was stated: 'We vividly convinced ourselves of it, when the Metropolitan of the mentioned Prince appeared in Rome, in front of the Holy See, with various chapters, most of which were superfluous and confusing, and some of them unacceptable..$^{16}$

From this negative assessment of the defined participation of the bishop, and then the Metropolitan of Visarion, in the negotiations, one can undoubtedly conclude that he was very principled and did not change his opinion in the positions he was guided with, based on the canon law of the Orthodox Church. On the same occasion, Strossmayer also wrote the letter to the Vatican Nuncio Vannutelli, which was forwarded to the State Secretary of Vatican, Cardinal Jakobini. The letter dates back to October 13, 1883, and he gave a number of objections to the draft Concordat given by Prince Nikola in cooperation with Metropolitan Visarion. However, bearing in mind the fact that this is the first legal act - an agreement between the Vatican and an Orthodox country, which could be a bridge and model for concluding the same or similar Concordats between the Vatican and other Orthodox countries, primarily having in mind the mighty Russian Empire, Strossmayer suggested the acceptation of this draft, which consisted of 34 articles. ${ }^{17} \mathrm{He}$ made the following proposal about the act of signing: 'If the Holy, Apostolic See, considers my script worthy, and if the Montenegrin Prince agrees with the alteration and the mentioned omitting, I think that the contract itself should be completed by the solemn signature in Vienna, so that, in that regard, Your Excellency, on behalf of the Holy See, and Visarion, the Bishop of Zahumlje, on behalf of Prince of Montenegro, receive the preliminary authorization and permission. And the reason for this is the following: 'when, approximately two years ago, abovementioned the Bishop of Zahumlje was in Rome, at the same time when I was in Rome, he was denied access to the Holy Father as a nonCatholic bishop..$^{18}$ Strossmayer emphasized that, after the ratification of the Concordat, it would be good to allow Bishop Visarion to meet the Pope, hoping that this audience would have a great impression of the Orthodox archpriest, who would, on return to his country, by the power of his authority, influence the people in Montenegro to change the attitude towards Roman Catholics and their head of the church. ${ }^{19}$

In correspondence with his closest and the most confidential associate, Canon Franjo Racki, Strossmayer expressed the most sincere thoughts about poor success of the initial phase of negotiations. He wrote to Racki: 'If I can appraise - at least something mistrust in me, caused by someone else's influence on the Montenegrin Prince that the thing did not succeed, then the clumsiness, the arrogance and one-sidedness of Rome justified by nothing were to blame for that. The guilty, especially from this side, was the

\footnotetext{
${ }^{16}$ Ibid, 267.

${ }^{17} \mathrm{Ibid}, 289-299$.

${ }^{18} \mathrm{Ibid}, 281-282$.

${ }^{19} \mathrm{Ibid}, 283$. It is interesting that Strossmayer, in the official correspondence of the highest rank, in letter of October 13,1883, addressed Visarion with the title he had in 1881. It is not possible that he, who carefully followed the church life in wide areas, did not know that Visarion was appointed and took over the service of the Metropolitan of Cetinje in November 1882. However, in the context of the given topic, it is not as important as emphasizing the far-sightedness of the Bishop of Djakovo in terms of Catholic-Orthodox relations in Montenegro and the entire Balkans.
} 
Participation of the Montenegrin Metropolitan Visarion in the First Phase of Negotiations between Montenegro ...

secretarius status. You know, in Rome, they hesitated to receive a Metropolitan of Montenegro. It was the arrogance which cannot be justified by anything in the world. Would Jesus do the same in similar circumstances? ${ }^{20}$

The name of the Metropolitan Visarion as one of the participants in the Concordat negotiations appeared shortly after the ratification of this act in the professional public. In the review published in the Journal of the History of Diplomacy (Revue d'histoire diplomatique, Paris), no. 4, from 1887, it was stated that the main negotiators from the Montenegrin side were Bishop Visarion and J. Sundečić, who, on behalf of the Montenegrin Government, signed the agreed text of the Concordat with Cardinal Jakobini, the State Secretary of the Holy See, on August $18,1886 .{ }^{21}$ And Cesare Tondini, a Catholic priest and a member of Barnabites, the Monastic Order, who, as the representative of Bishop Strossmayer, participated in negotiations with the representative of the Montenegrin Prince, Protoiereus Jovan Sundečić, who at that time had the title of Prince's Secretary, stated in one discussion: 'after the expansion of the Montenegrin territory and the recognition of its autonomy at the Berlin Congress, Prince Nikola sent to Rome a Montenegrin Bishop, Mr. Visarion, who will become the Metropolitan of Cetinje, to resolve the position of Catholics in the Principality with the Holy See. The services of Mr. Durando, the representative of Italy in Montenegro at that time, contributed to this. Mr. Durando co-operated on a project that was led by Monsignor Visarion, which was then used as a starting point on the way to this Concordat'. 22

Duke Simo Popović, although a contemporary and witness, and a participant in one part of establishment and conclusion process of the Concordat, who could not have been unacquainted with the role of the Metropolitan Visarion, in his extensive Memoirs, left the poor note about this: 'In Russia, they were not satisfied with Prince regarding this job. Holy Synod, precisely Pobedonostsev, the most eminent person on the imperial court, was bitter toward Prince and scolded him that he opened 'the gate of Montenegro' wide to the enemy of Orthodoxy. Prince defended himself against indictments by proving that he had to conclude the agreement with Rome because of Austria, taking away its patronage of the Roman Catholic clergy and population in Montenegro, and the possibility to use them for its own politics. He was pleased with his own success. The Croats and the rest of the Catholic world were full of praise for him, and even more, when in next 1887, he asked for service in Old Slavic language in the Archdiocese of Bar, which was approved, with the Glagolitic Missal, by the council and confirmed by the Pope on March 31. The Montenegrin Catholics were indifferent to it. All but the ones in Bar speak only Albanian language. They understood neither the service in Slavic nor the one in Latin language. ${ }^{23}$

\footnotetext{
${ }^{20}$ Correspondence Racki - Strossmayer, Vol. 3, F. Sisic, (ed.), JAZU, Zagreb 1930, 23-24. About the beginning of the negotiations on the establishment of the Concordat, Strossmayer informed Racki via letters and during the meetings when he was giving him the documentation regarding the issue. Correspondence Racki Strossmayer, Vol. 2, F. Sisic, (ed.), JAZU, Zagreb 1929, 224; 227; 231-232.

${ }^{21}$ Quoted by: Ljubomir Durkovic Jaksic, The Serbs and the Vatican 1804-1918. Kraljevo 1990, 329. About this also see Diplomacy of Montenegro, by Radoslav Raspopovic 1711-1918. Historical Institute, Podgorica 1996, 487-488.

${ }^{22}$ Cesare Tondini de Quarenghi, De la Reunion des Eglises, Societe de Saint Augustin, Lille 1892, 2.

${ }^{23}$ Duke Simo Popovic, Memoirs, ed. J. Bojovic and H. Rakocevic, Historical Institute, Cetinje 1995, 604.
} 
The fact that the Concordat, which dates back to 1886, represents a compromise that has matured over time and which respects the interests of the contracting parties represented its stronger side. In the next half of the century, the agreement with Montenegro was a necessary starting point for all negotiations that the Holy See had with predominantly Orthodox countries. Taken as an explicit model for the Concordat with Serbia from 1914, it continued with such an influence until the period between the two world wars and until the Concordat with Romania in 1927 and Yugoslavia in 1934. Such function of it came completely to the end after World War II, when the communist regime in Eastern Europe made any agreement with the Catholic Church impossible. In this context, as it can be seen from the historical sources, the role of bishop - Metropolitan of Visarion Ljubiša is of great importance for the final outcome of the negotiations and the formulation of the text of the Concordat between the Holy See and Montenegro. Although many documents and testimonies have not been preserved, which is implicit in such a delicate diplomatic mission, an undoubted conclusion about the unique attitude of Prince Nikola and his representative in negotiations, Bishop Visarion Ljubiša, the famous figure in Montenegrin society at the end of the 19th century, who, besides the church service, was also remembered as the first minister of education in Montenegro, can be deduced from this presentation. ${ }^{24}$

\section{Literature}

[1] Archive of Metropolitanate of Montenegro and the Littoral (AMML) - Cetinje Metropolitanate Fond (CM)

- Personal files of Metropolitans: Ilarion, Visarion and Mitrofan

[2] Archive of the Praskvica monastery

[3] The Royal Museum of King Nikola - Archives and Library Departments Fond (ALDRM)

- Nikola I Fond (NI)

[4] State Archives of Montenegro, Cetinje (SAM) - Ministry of Education and Church Affairs Fond (MECA)

- Department in Budva, the Legacy of Ljubisa family

[5] Duke Simo Popovic, Memoirs, ed. J. Bojovic and H. Rakocevic, Historical Institute, Cetinje, 1995, 604.

[6] Gligor Stanojevic, 'Contributions to diplomatic history of Montenegro from the Berlin Congress until the end of the XIX century', Historical journal, vol. 11 (1960), 166.

[7] Dionisije Mikovic, Metropolitan of Montenegro Visarion Ljubisa, Novi Sad 1886.

[8] Durkovic Jaksic, Serbs and Vatican 1804-1918, Kraljevo, 1990.

[9] Djoko Slijepcevic, History of the Serbian Orthodox Church, Vol. 2, Bigz, Belgrade, 1991.

[10] Correspondence Josip Juraj Strossmayer - Serafino Vannutelli 1881-1887, ed. J. Balobanic and J. Kolanovic, Zagreb 1999, 259, 267, 281-282, 283, 289-299.

[11] Correspondence Racki - Strossmayer, Book 3, F. Sisic, (ed.), JAZU, Zagreb 1930, 23-24.

[12] Correspondence Racki - Strossmayer, Book 2, F. Sisic, (ed.), JAZU, Zagreb 1929, 224; $227 ; 231-232$.

\footnotetext{
${ }^{24}$ Metodije Ostojic, 'Catalog - Diptych of Metropolitans of Zeta, Montenegro and Littoral' in: Monastery of the Birth of the Most Holy Mother of God 1484-2014, Cetinje, 2014 461-465.
} 
Participation of the Montenegrin Metropolitan Visarion in the First Phase of Negotiations between Montenegro ...

[13] Ljubomir Durkovic Jaksic, Serbs and Vatican 1804-1918, Kraljevo 1990, 329.

[14] Metodije Ostojic, 'Catalog - Diptych of Metropolitans of Zeta, Montenegro and Littoral' in Monastery of the Birth of the Most Holy Mother of God 1484-2014, Cetinje, 2014, 461-465.

[15] Pavle Kondic, Metropolitanate of Montenegro and the Littoral in the second half of the 19th and early 20th century (1851-1920), Belgrade 2014, 158-163. Manuscript, a copy in the Metropolitanate Library, in Cetinje.

[16] Pavle Kondic, Seminary in Cetinje and its spiritual and educational light, Seminary of Saint Peter of Cetinje, Cetinje, 2005.

[17] Rados Ljusic. History of Serbian Statehood - Serbia and Montenegro, Vol. 2, Novi Sad 2011, 337-354.

[18] Radoslav Raspopovic, Diplomacy of Montenegro 1711-1918. Historical Institute, Podgorica 1996, 487-488.

[19] Sava, Bishop of Sumadija, Serbian Hierarchs from the 9th to the 20th century, Belgrade 1997, 88-89.

[20] Francesco Kakamo, the Concordat with Montenegro and the policy of the Holy See towards the East, http://www.montenegrina.net/pages/pages1/religija/konkordat_sa_cg.htm (August 9, 2018).

[21] http://en.wikipedia.org/wiki/Luigi_Jacobini; (June 20, 2018).

[22] http://www.catholic-hierarchy.org/bishop/bjaco.html (June 20, 2018).

[23] Cesare Tondini de Quarenghi, De la Reunion des Eglises, Societe de Saint Augustin, Lille 1892, 2. 